\title{
Construction of an anti-programmed death-ligand 1 chimeric antigen receptor and determination of its antitumor function with transduced cells
}

\author{
JIASEN XIE ${ }^{1-3}$, ZISHAN ZHOU $^{2,3}$, SHUNCHANG JIAO $^{2}$ and XIAOKUN LI ${ }^{1}$ \\ ${ }^{1}$ Department of Biochemistry, College of Basic Medical Sciences, Jilin University, Changchun, Jilin 130021; \\ ${ }^{2}$ Department of Medical Oncology, Chinese People's Liberation Army General Hospital, Beijing 100853; \\ ${ }^{3}$ Beijing Bio DC Labs, Beijing 102206, P.R. China
}

Received October 2, 2017; Accepted March 7, 2018

DOI: $10.3892 / \mathrm{ol} .2018 .8617$

\begin{abstract}
A chimeric antigen receptor (CAR) is a type of fusion protein that comprises an antigen-recognition domain and signaling domains. In the present study, a programmed death-ligand 1 (PD-L1)-specific CAR, comprised of a single-chain variable fragment $(\mathrm{scFv})$ derived from a monoclonal antibody, co-stimulatory domains of cluster of differentiation (CD) 28 and 4-1BB and a T-cell-activation domain derived from $\mathrm{CD} 3 \zeta$, was designed. The construction was cloned and packaged into the lentiviral vector pLVX. Flow cytometry confirmed that peripheral blood mononuclear cells were efficiently transduced and that the CAR was successfully expressed on T cells. The cytotoxicity of transduced T cells was detected using PD-L1-positive NCI-H358 bronchioalveolar carcinoma cells and A549 lung adenocarcinoma cells (with a low expression of PD-L1, only in the A549 cells). The results demonstrated mild cytotoxicity at an effector-to-target ratio of 10:1. An ELISA revealed a significant increase in the level of interferon- $\gamma$ released from $\mathrm{T}$ cells transduced with $\mathrm{scFv}-28 \mathrm{Bz}$ when the cells were co-cultured with PD-L1-positive NCI-H358 cells, while interkeukin- 2 and tumor necrosis factor- $\alpha$ levels remained unchanged. These data indicated a potential method for the treatment of solid tumors.
\end{abstract}

Correspondence to: Professor Xiaokun Li, Department of Biochemistry, College of Basic Medical Sciences, Jilin University, 126 Xinmin Street, Changchun, Jilin 130021, P.R. China

E-mail: xiaokunli@163.net

Professor Shunchang Jiao, Department of Medical Oncology, Chinese People's Liberation Army General Hospital, 28 Fuxing Road, Beijing 100853, P.R. China

E-mail: jiaosc@vip.sina.com

Key words: chimeric antigen receptor, programmed death-ligand 1, NCI-H358, A549

\section{Introduction}

Lung cancer was the most common cancer and the leading cause of cancer-associated mortality in China in 2015 (1), followed by gastric cancer, esophageal cancer and liver cancer. Non-small cell lung cancer (NSCLC) accounts for $80-90 \%$ of lung cancer cases $(2,3)$. The primary treatment for stage I-II NSCLC is surgery; however, the majority of NSCLC diagnoses occur at stage IV (4). In addition to small molecule inhibitors, tyrosine kinase inhibitors and monoclonal antibodies, immunotherapy has been used as a primary treatment method (5).

Chimeric antigen receptors (CARs) are fusion proteins that comprise $\geq 3$ main domains: The antigen-binding domain, usually a single-chain variable fragment (scFv) of antibody responsible for recognition and binding; the intracellular domain; and the transmembrane sequence, which connects the extracellular region to the intracellular domain (6-8). The CAR molecule has been developed through three stages according to the intracellular signaling domain: The first generation of CARs consisted of only one cluster of differentiation (CD) $3 \zeta$ chain; the second generation was comprised of one co-stimulatory molecule and a $\mathrm{CD} 3 \zeta$ chain; and the third generation comprised $\geq 2$ co-stimulatory molecules with $\mathrm{CD} 3 \xi$ as the last signal transduction region. Once a CAR molecule is expressed on a CAR-T cell and the tumor antigen is recognized by the $\mathrm{scFv}$, the CAR-T cell is activated and lyses the target cells (9). In 2003, the first preclinical study to demonstrate the effectiveness of anti-CD19 was published (10), and a series of studies based on different target molecules have subsequently been conducted (11-17). Due to antibody specificity, CAR-T cells may effectively bind to an antigen independently of major histocompatibility complex restriction (18), and an increasing number of studies have demonstrated positive outcomes for patients following treatment with CAR-T cells (19-23).

Programmed death 1 (PD-1) is a receptor that is involved in apoptosis (24). One study on PD-1-deficient mice has indicated that PD-1 functions to negatively regulate immune responses (25). At present, the consensus is that PD-1 acts as an immune-checkpoint receptor and is involved in regulating $\mathrm{T}$ cell activity to inhibit immune responses and prevent overstimulation in peripheral tissues (26-29). Programmed 
death-ligand 1 (PD-L1), one of the two ligands of PD-1, was identified and subsequently termed PD-L1 (PdcdIIII), the study of which provided convincing evidence that $\mathrm{T}$ cells exhibited lower proliferative ability when cultured with an anti-CD3 antibody (30-32).

Recently, several studies have revealed a high expression level of PD-L1 in patients with NSCLC (33), and have demonstrated its association with the mechanism underlying tumor immune escape $(34,35)$. Effective blocking of PD-1 or PD-L1 has a positive effect on the treatment of cancer together with combination treatment methods (36-40). CAR-T cells secreting anti-PD-L1 antibodies have also demonstrated promising efficacy (41). Furthermore, the expression of a dominant negative receptor or switch of co-stimulatory receptor may achieve the same purpose to prevent inactivation of T cells (42-44). Based on the results of previous studies, a CAR was designed comprising an anti-PD-L1 scFv and an intracellular co-stimulation signal from CD28 and 4-1BB (PD-L1 scFv-CD28-CD137-CD3z), which was inserted into a high-quality lentivirus for transduction into peripheral blood mononuclear cells (PBMCs) (45-47). The function of CAR-T cells was confirmed by a flow cytometric apoptosis assay following co-culture with NCI-H358 or A549 cells at a ratio of 10:1. The levels of interferon (IFN) $-\gamma$, interleukin (IL)-2 and tumor necrosis factor (TNF)- $\alpha$ in the supernatant of the co-culture were detected by ELISA. The results indicated mild antitumor activity and a protective effect of $\mathrm{T}$ cells against PD-L1 by blocking PD-L1.

\section{Materials and methods}

Reagents and sequences. RPMI-1640 culture medium and the Dynabeads Human T-Activator CD3/CD28 kit were purchased from Gibco; Thermo Fisher Scientific, Inc. (Waltham, MA, USA). The Annexin V Apoptosis kit with 7-aminoactinomycin (7-AAD) and the carboxyfluorescein succinimidyl ester (CFSE) Cell Division Tracker kit were obtained from BioLegend, Inc. (San Diego, CA, USA). Fluorescein isothiocyanate (FITC)-Protein L was purchased from ACROBiosystems (Newark, DE, USA). All restriction endonucleases were purchased from Thermo Fisher Scientific, Inc., and the ligation kit was obtained from New England BioLabs, Inc. (Ipswich, MA, USA). The homologous recombination kit and chemically competent cell Stbl3 ${ }^{\text {тм }}$ were provided by Beijing TransGen Biotech Co., Ltd. (Beijing, China). The lentiviral vector $\mathrm{pLVX}$ was provided by Clontech Laboratories, Inc. (Mountainview, CA, USA). DNA sequences were synthesized by Thermo Fisher Scientific, Inc. Lentivirus concentrator reagent was obtained from Beijing Syngentech Co., Ltd. (Beijing, China). All fluorescent antibodies used for flow cytometric analysis were purchased from BioLegend, Inc. (PD-L1/PD-1) or BD Biosciences (CD4 and CD8; Franklin Lakes, NJ, USA).

Cell culture. NSCLC NCI-H358 and A549 cells were provided by ATCC (Manassas, VA, USA) and cultured in RPMI-1640 medium (cat no. 11875119) with $10 \%$ fetal bovine serum (FBS; cat no. 10099141; both Thermo Fisher Scientific, Inc.) in a $5 \% \mathrm{CO}_{2}$ atmosphere at $37^{\circ} \mathrm{C}$. PBMCs (obtained from Mr Jiasen Xie and Miss Zishan Zhou, Beijing Bio DC Labs,
Beijing, China) were activated by Dynabeads and cultured in X-VIVO ${ }^{\mathrm{TM}} 15$ chemically defined, serum-free hematopoietic cell medium (cat no. 04-418Q; Lonza Group, Ltd., Basel, Switzerland) with $5 \% \mathrm{FBS}$ in a $5 \% \mathrm{CO}_{2}$ atmosphere at $37^{\circ} \mathrm{C}$.

Construction of vector and production of lentivirus. The lentiviral vector pLVX (cat no. 631982; Clontech Laboratories, Inc.) was digested with EcoRI and NotI, prior to being recovered with a Gel DNA Recovery kit (cat no. DP209; Tiangen Biotech Co., Ltd., Beijing, China). A scFv fragment, designated FR1 (Invitrogen; Thermo Fisher Scientific, Inc.), which comprised scFv and a transmembrane domain, was amplified from a pUC-vector using the following primers: FR1 forward, 5'-GTGTCGTGAGGATCTATTTCCGGTGAA TTCGCCGCCACCATGGCCTTACCAGTGACCGCC-3' and reverse, 5'-TCTGGACCGCTTAGATCGGTTCCTATGATT TCGGTTCCTATGATTACA ATAAAGAGTAAT-3'. A signal fragment containing a transmembrane domain, CD137 co-stimulatory domain and a CD28 co-stimulatory domain was amplified from a pUC-vector (Invitrogen; Thermo Fisher Scientific, Inc.) and termed FR2, using the following primers: FR2 forward, 5'-ATTACTCTTTATTGTAATCAT AGGAACCGAAATCATAGGAACCGATCTAAGCGGTCC AGA-3' and reverse, 5'-GTAATCCAGAGGTTGATTGAT CCGCGGCCGCCTACCGTGGGGGGAGGGCCTGCATAT GAA-3'. Platinum $^{\mathrm{TM}} P f x$. The DNA template plasmid pUC-FR1 and pUC-FR2 were synthesized by Invitrogen; Thermo Fisher Scientific, Inc. DNA polymerase (cat no. 11708039; Thermo Fisher Scientific, Inc.) was used according to the manufacturer's protocol, and the thermocycling conditions were as follows: $94^{\circ} \mathrm{C}$ for $2 \mathrm{~min}, 94^{\circ} \mathrm{C}$ for $15 \mathrm{sec}, 58^{\circ} \mathrm{C}$ for $30 \mathrm{sec}$, $68^{\circ} \mathrm{C}$ for $2 \mathrm{~min}, 30$ cycles and $68^{\circ} \mathrm{C}$ for $5 \mathrm{~min}$. PCR products were subjected to $1 \%$ agarose gel electrophoresis and stained with $0.5 \mu \mathrm{g} / \mathrm{ml}$ ethidium bromide at room temperature for $30 \mathrm{~min}$ and observed at $254 \mathrm{~nm} \mathrm{UV}$. The specific bands were recovered with a gel extraction kit. A seamless homologous recombination with FR1, FR2 and the digested vector pLVX was performed to obtain the $\mathrm{scFv}-28 \mathrm{Bz}$ expression recombination vector. The recombination product was transformed into Stbl3 ${ }^{\mathrm{TM}}$ competent cells, which were selected on ampicillin plates. The positive clones were used for sequencing.

The validated vector pLVX-EF $1 \alpha-\mathrm{scFv}-28 \mathrm{Bz}$ was used to produce lentiviral particles with the 2 nd generation package system psPAX2 and pMD2.G. The LipoFiter ${ }^{\mathrm{TM}}$ Liposomal Transfection reagent was purchased from Hanbio Biotechnology Co.,Ltd. (Shanghai, China) and all procedures were performed according to the manufacturer's protocols. A total of $30 \mu \mathrm{g}$ plasmid were transfected (containing $15 \mu \mathrm{g}$ pLVX-EF1 $\alpha$-scFv-28Bz, $7.5 \mu \mathrm{g}$ psPAX2 and $7.5 \mu \mathrm{g}$ pMD2.G). The lentiviruses in the cell culture supernatant were collected at 48 and $72 \mathrm{~h}$ post-transfection and were concentrated by PEG8000 reagent from the BioGeek ${ }^{\mathrm{TM}}$ Lentivirus Concentrate kit (cat no. BG20101L; Beijing Syngentech Co., Ltd.). In order to ensure the reliability of the system, parallel experiments were also conducted. The same empty lentivector of LV-EF1 $\alpha-\mathrm{scFv}-28 \mathrm{Bz}$ was constructed to express green fluorescent protein (GFP) in the same multiple cloning site and following the same EF1 $\alpha$ promoter to produce LV-EF1 $\alpha$-GFP. The lentivector was packaged in lentiviral particles with the same packaging 
system and the particles were transfected into PBMCs as the LV-EF1 $\alpha$-scFv-28Bz particles would be transfected into PBMCs. The expression of GFP was confirmed to ensure the reliability of vector system, packaging system and transfection efficiency.

Cell expansion and transduction. PBMCs were activated by Dynabeads at a bead-to-cell ratio of 1:1 in X-VIVO ${ }^{\mathrm{TM}}$ 15 chemically defined medium with $30 \mathrm{IU} / \mathrm{ml} \mathrm{rIL}-2$ (cat no. Z03074-10; GenScript, Piscataway, NJ, USA), and incubated in a humidified $5 \% \mathrm{CO}_{2}$ incubator at $37^{\circ} \mathrm{C}$. A total of 3-5 days later, the activated cells were resuspended and $\sim 2$ million PBMCs were transduced with pre-conditioned lentiviral particles with or without $\mathrm{scFv}-28 \mathrm{Bz}$ in serum-free $\mathrm{X}-\mathrm{VIVO}^{\mathrm{TM}} 15$ chemically defined medium with a final concentration of $10 \mu \mathrm{g} / \mathrm{ml}$ Polybrene ${ }^{\circledR}$ (Sigma-Aldrich; Merck $\mathrm{KGaA}$, Darmstadt, Germany), centrifuged at $270 \mathrm{x}$ g at $32^{\circ} \mathrm{C}$ for $1 \mathrm{~h}$ with a parallel control (virus control - empty lentivirus particles without scFv-28Bz + PMBC; cell control - X-VIVO ${ }^{\mathrm{TM}}$ 15 medium + PBMC; controls centrifuged at $270 \mathrm{x}$ g for $1 \mathrm{~h}$ at $32^{\circ} \mathrm{C}$ ) and cultured in a humidified $5 \% \mathrm{CO}_{2}$ incubator at $37^{\circ} \mathrm{C}$ for $24 \mathrm{~h}$. The medium was changed to full-nutrient medium (X-VIVO ${ }^{\mathrm{TM}} 15$ with $5 \% \mathrm{FBS}$ ) after $24 \mathrm{~h}$ and fresh medium was added according to growth status every 2 days, with a density of 1-2 million cells/ml.

Detection of CAR molecule in transduced cells and PD-L1 in tumor cell lines. As reported previously, the protein L has the ability to bind to the $\kappa$ light chain of antibodies (48). Flow cytometry was used to confirm the expression of $\mathrm{scFv}-28 \mathrm{Bz}$ using the FITC-Protein-L reagent (cat no. RPL-PF141; ACROBiosystems). PBMCs ( 2 million) were harvested using centrifugation at $300 \mathrm{x}$ g for $10 \mathrm{~min}$ at $25^{\circ} \mathrm{C}$, washed twice with phosphate-buffered saline (PBS) and incubated with $2 \mu \mathrm{g}$ FITC-Protein-L protein at room temperature for $1 \mathrm{~h}$ in the absence of light, with FITC-Protein-L-stained mock cells serving as the isotype control. Subsequently, the cells were washed three times in PBS containing $0.5 \%$ bovine serum albumin (BSA). NCI-H358 and A549 cells ( 2 million) were harvested by digestion with trypsin and washed twice with PBS. The cell lines were incubated with $2 \mu \mathrm{g}$ phycoerythrin (PE)-anti-PD-L1 (PE anti-human CD274 Antibody; 1:10, cat no. 329706) at room temperature for $30 \mathrm{~min}$, prior to being washed three times in PBS containing $0.5 \% \mathrm{BSA}$. The cells were analyzed with a BD FACSCalibur flow cytometer and the results were analyzed with FlowJo software 7.6.1 (FlowJo LLC, Ashland, OR, USA).

Analysis of subsets of PBMCs and PD-1 expression. CD4 ${ }^{+}$ CAR-T cells provided assistance to $\mathrm{CD} 8^{+} \mathrm{CAR}-\mathrm{T}$ cells in vitro and in vivo, as the proportion of CD4+ cells and CD8+ cells in CAR-T are associated with therapeutic efficacy (49). In order to compare the cytotoxicity of tumors with different expression levels of PD-L1, the expression level of PD-1 on T cells should be similar, to avoid differences in cell viability due to PD-L1 (30). PBMCs were collected at 14 days post-transduction and were washed using PBS twice. A total of $2 \times 10^{6}$ PMBC cells were incubated at room temperature for 30 min with a mixture of peridinin chlorophyll protein
complex-CD4 (cat no. 347324) and PE-CD8 (cat no. 340046) antibodies, while the remaining cells were incubated with an allophycocyanin-conjugated anti-human PD-1 antibody (cat no. 329908) for $30 \mathrm{~min}$ at room temperature, with normal immunoglobulin G (IgG; PerCP-Mouse IgG1 isotype; cat no. 550672; PE-Mouse IgG1 isotype; cat no. 550617; both BD Biosciences; APC-Mouse IgG1 isotype; cat no. 400120; BioLegend, Inc.) used as an isotype control. All antibodies had a dilution of 1:10. Following washing three times in PBS containing $0.5 \% \mathrm{BSA}$, the cells were analyzed by a flow cytometer and the results were analyzed with FlowJo software 7.6.1.

Detection of IFN- $\gamma, I L-2$ and TNF- $\alpha$ production by $T$ cells. In order to ensure that the interaction of $\mathrm{T}$ cells with target cells was able to induce the production of cytokines, $\mathrm{T}$ cells were co-cultured with NCI-H358 or A549 cells at a ratio of $1: 1$ overnight at $37^{\circ} \mathrm{C}$ in serum-free medium $\left(\mathrm{X}-\mathrm{VIVO}{ }^{\mathrm{TM}}\right.$ 15 chemically defined medium), and the supernatants were collected for cytokine detection by ELISA kits, as follows: Human IFN- $\gamma$ ELISA kit (cat. no. DKW12-1000-096), Human IL-2 ELISA kit (cat no. DKW12-1020-096) and Human TNF- $\alpha$ ELISA kit (cat no. DKW12-1720-096; all Dakewe Biotech Co., Ltd., Shenzhen, China).

Flow cytometric analysis of cell apoptosis. As a reliable way to detect lytic activities of effector cells $(50,51)$, flow cytometry has the advantages of good repeatability and sensitivity. CFSE-labeled NCI-H358 or A549 cells (1x10 6 cells/well) were seeded onto 12 -well culture plates on day 0 . PBMCs $\left(1 \times 10^{7}\right.$ cells/well) were plated into the 12 -well culture plates for co-culturing with NCI-H358 or A549 cells for $3.5 \mathrm{~h}$ at $37^{\circ} \mathrm{C}$ and $5 \% \mathrm{CO}_{2}$ in a cell incubator. Subsequently, all the cells from each well were collected, and were centrifuged for $10 \mathrm{~min}$ at $200 \mathrm{x} \mathrm{g}$ at $25^{\circ} \mathrm{C}$ and washed three times in PBS. The cells were resuspended in $100 \mu \mathrm{l}$ binding buffer with Annexin V/7-AAD (cat no. 640930; Biolegend, Inc.) and incubated for $30 \mathrm{~min}$ at room temperature in the dark. Following being washed with PBS containing 0.5\% BSA, the cell mixtures were collected and resuspended in $100 \mu \mathrm{l}$ PBS. Non-co-cultured target cells served as a parallel control to detect spontaneous cell death. The labeled cells were analyzed using a flow cytometer. Data were collected and analyzed with FlowJo software 7.6.1 to determine the percentage of apoptotic cells. The specific cytotoxicity of PBMCs was equal to the total death of co-cultured target cells following subtraction of the total spontaneous death of non-co-cultured target cells [specific cytotoxicity=target cell co-cultured $_{\text {Q }}\left(+\mathrm{Q}_{2}+\mathrm{Q} 3\right)$ - target cell $\left._{\text {non-co-cultured }}(\mathrm{Q} 1+\mathrm{Q} 2+\mathrm{Q} 3)\right]$.

Statistical analysis. Experiments were repeated $\geq 3$ times and all the results are presented as the mean \pm standard deviation. The GraphPad Prism 6.0 software (GraphPad Software, Inc., La Jolla, CA, USA) was used for statistical analyses. The pairwise mean comparisons were performed using an unpaired Student's t-test in the cell apoptosis assay and one-way analysis of variance, followed by Tukey's multiple comparisons test, was applied to analyze the data following ELISA detection. $\mathrm{P}<0.05$ was considered to indicate a statistically significant difference. 


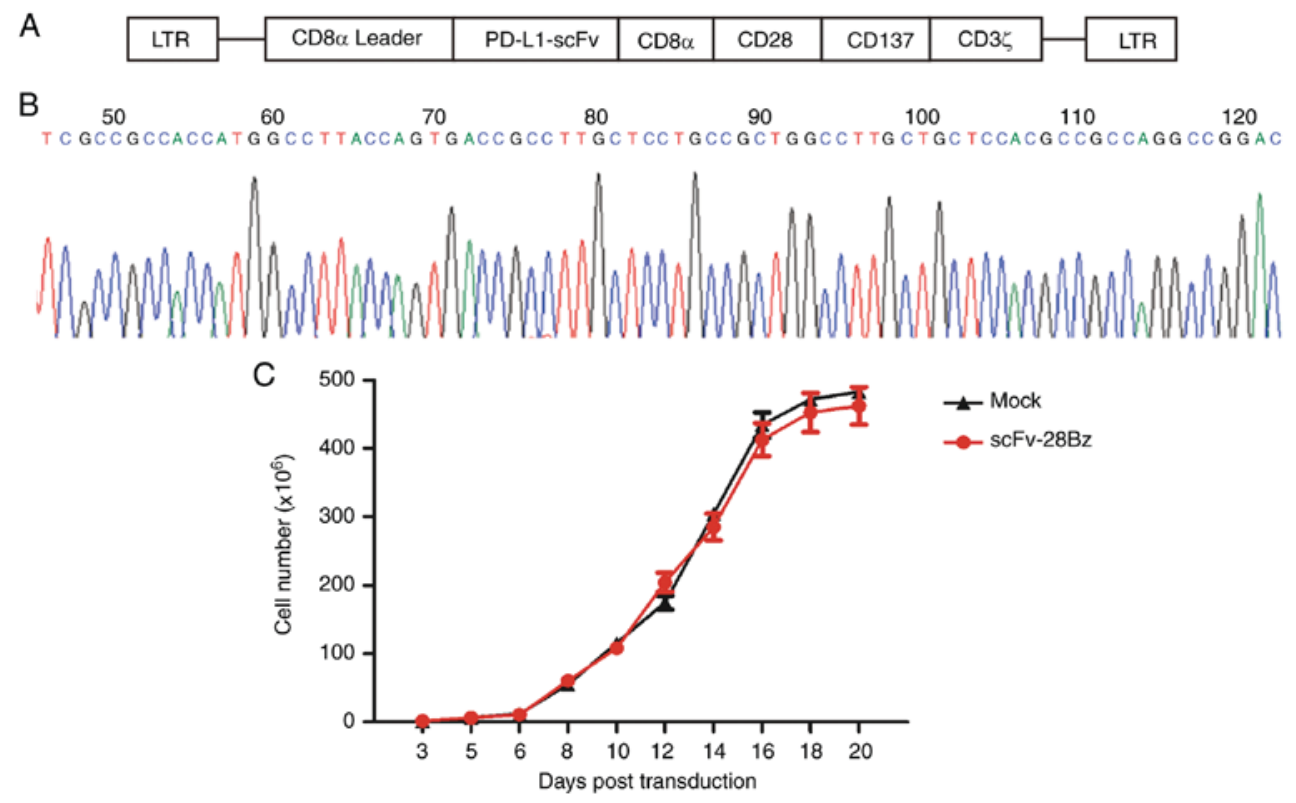

Figure 1. Schematic diagram of the PD-L1-chimeric antigen receptor plasmid and the sequencing results. (A) Structure of the lentiviral vector PD-L1-scFv-CD28Bz. (B) Sequencing results. (C) Cell expansion of transduced T cells from day 3-20 post-transduction. LTR, long terminal repeat; CD8a leader, signal peptide of $\mathrm{CD} 8 \alpha$; scFv, single-chain variable fragment; $\mathrm{CD} 8 \alpha$, hinge and transmembrane of $\mathrm{CD} 8 \alpha ; \mathrm{CD} 28$, cytoplasmic domain of $\mathrm{CD} 28$; $\mathrm{CD} 3 \zeta$, cytoplasmic region of CD3 $;$; PD-L1, programmed death-ligand 1.

\section{Results}

Successful construction of PD-L1-specific scFv-28Bz and efficient expansion of cells. One type of lentiviral vector (LV-EF1 $\alpha$-scFv-28Bz) was constructed successfully. As demonstrated in Fig. 1A, the vector contained PD-L1 scFv, a scFv from MPDL3280A (52), and transmembrane domains from $\mathrm{CD} 8 \alpha$, a $\mathrm{CD} 28$ co-stimulatory domain, a CD137 co-stimulatory domain and a CD3ל intracellular domain (Fig. 1A). The $5^{\prime}$ terminal sequencing results are depicted in Fig. 1B. The PBMCs were cultured in X-VIVO ${ }^{\text {тм }} 15$ chemically defined medium with 5\% FBS post-transduction, and the cell numbers were counted; according to cell growth status, fresh medium was supplemented to maintain a density of 1-2 million cells $/ \mathrm{ml}$. As depicted in Fig. 1C, the total cell number reached 200-300 million at day 14-21 post-transduction.

Expression of CAR on transduced cells and differential $P D$-L1 expression in tumor cell lines. The FITC-Protein L may effectively bind to the $\mathrm{k}$-light chain of $\mathrm{scFv}$, as reported by Zheng et al (48). As depicted in Fig. 2A, according to FITC-Protein L staining, the scFv-28Bz-positive cells accounted for $\sim 39 \%$ of the total cells, compared with $<1 \%$ in the non-transgenic control, which indicated that $\mathrm{scFv}-28 \mathrm{Bz}$ was efficiently expressed on T cells. PD-L1 was expressed on $6.97 \%$ of A549 cells and $85.1 \%$ of NCI-H358 cells, as depicted in Fig. 2B. Therefore, A549 was selected to represent negative PD-L1 expression, while NCI-H358 was used as the PD-L1-positive cell line. As a systematic parallel experimental control, the LV-EF1 $\alpha$-GFP virus had a high infection efficiency in PBMCs, as depicted in Fig. 2C. The transfection efficiency of the viral system ensured the reliability of the expression of the CAR on the PBMCs.
$\mathrm{CD}^{+}$and $C D 8^{+}$cells account for the majority of PBMCs, and PD1 is highly expressed in these cells. On day 14 post-transduction, the cells were collected to analyze the subsets of $\mathrm{CD}^{+}$and $\mathrm{CD} 8^{+}$cells and the expression of PD-1. As depicted in Fig. 3A, the $\mathrm{CD}^{+}$subset accounted for $10-30 \%$ of the total number of cells, and the $\mathrm{CD} 8^{+}$subset accounted for $70-90 \%$ of the total number of cells. The expression of PD-1 was 30-50\%, as depicted in Fig. 3B.

IFN- $\gamma, I L-2$ and TNF- $\alpha$ production in $T$ cells. The results revealed that the co-culture of transduced $\mathrm{T}$ cells with NCI-H358 cells induced significantly increased production of IFN- $\gamma$, compared with mock $\mathrm{T}$ cells with NCI-H358 $(\mathrm{P}<0.01$; Fig. 4A), but the levels of IL-2 and TNF- $\alpha$ were low. The levels of cytokines in the supernatants of co-cultured cells with A549 cells were $<40 \mathrm{pg} / \mathrm{ml}$ (Fig. 4B).

Transduced $T$ cells exhibit a mild ability to kill NCI-H358 cells, but not A549 cells. The cytotoxicity percentages of mock and scFv-28Bz T cells against NCI-H358 cells were $5 \pm 1.7$ and $17.3 \pm 1.8 \%$, respectively (Fig. $5 \mathrm{~A}$ ), and $\mathrm{scFv}-28 \mathrm{Bz}$ was significantly higher, compared with the mock control group $(\mathrm{P}<0.01)$. The cytotoxicity percentages of mock and $\mathrm{scFv}-28 \mathrm{Bz} \mathrm{T}$ cells against A549 cells were $7.3 \pm 2.77$ and $4.5 \pm 3.96 \%$, respectively, and there was no significant difference between these groups (Fig. 5B). The morphology of co-cultured cells also demonstrated specific cytotoxicity of CAR-T cells against PD-L1 ${ }^{+}$NCI-H358 cells, but no significant effect on A549 cells expressing low PD-L1 levels (Fig. 6).

\section{Discussion}

Lung cancer is a lethal disease, the etiopathogenesis of which is varied and complex (53-55). There are several types of 

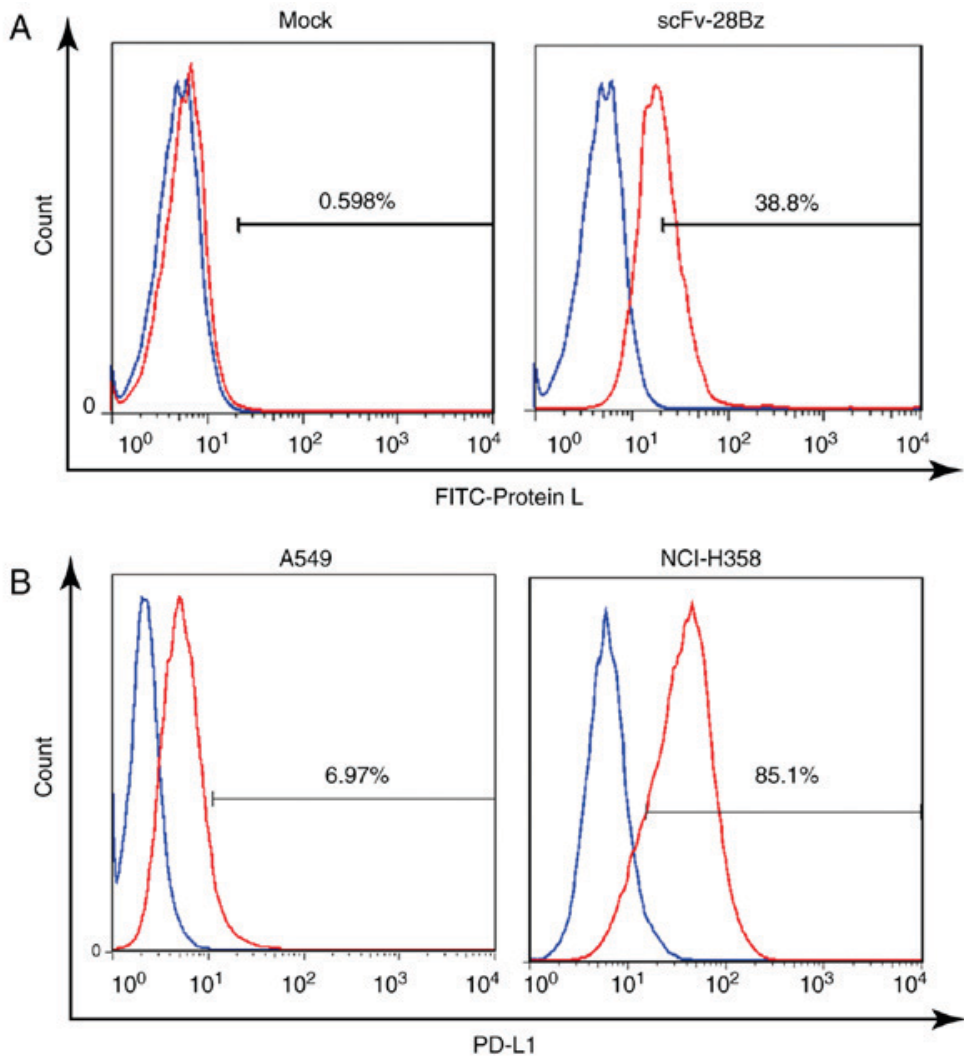

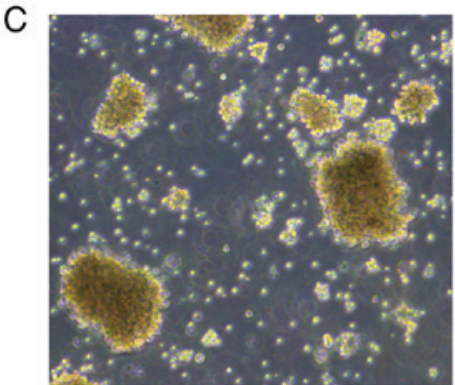

Bright field

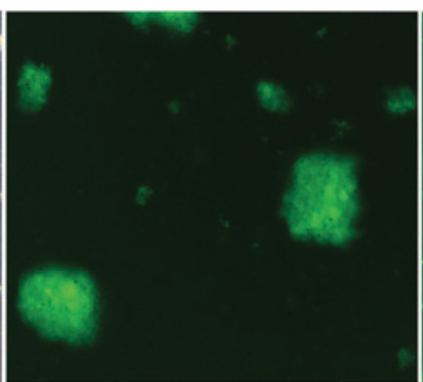

Fluorescence

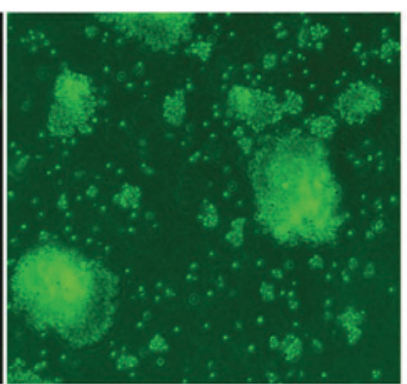

Merge

Figure 2. Analysis of scFv-28Bz surface expression and PD-L1 expression in A549 and NCI-H458 cells. (A) PBMCs labeled with FITC-Protein-L were analyzed by flow cytometry. Mock represents the control; scFv-28Bz was transduced by the virus LV-EF1 $\alpha$-scFv-28Bz. (B) Expression of PD-L1 in A549 or NCI-H358 cells was detected by flow cytometry using a phycoerythrin-labeled anti-PD-L1 antibody, with normal immunoglobulin G as an isotype control. (C) PBMCs were transduced by the virus LV-EF1 $\alpha$-GFP, and the images depict GFP fluorescence and were captured $48 \mathrm{~h}$ after virus infection. FITC, fluorescein isothiocyanate; PD-L1, programmed death-ligand $1 ; \mathrm{scFv}$, single-chain variable fragment; GFP, green fluorescent protein; PBMCs, peripheral blood mononuclear cells.

lung cancer, and different treatment methods are adopted depending on the type and level of development; however, more effective treatment programs are required $(3,56)$. In recent years, immunotherapy has provided a good option for the treatment of lung cancer, and is expected to relieve the pain induced by cancer (3). Previous CAR-T cell studies based on CD19 as a target have demonstrated positive effects $(19,20,45,57)$. Furthermore, increasing evidence on immune checkpoints has provided a potential novel approach to tumor therapy $(36,37,58-61)$. In 2014, PD-L1 immunotherapy utilizing a monoclonal antibody, MPDL3280A, was demonstrated to be effective in the treatment of metastatic urothelial bladder cancer, and this therapy received breakthrough designation status by the US Food and Drug Administration in June 2014 (62). Using the monoclonal antibody MPDL3280A, another study also demonstrated the inhibition of a variety of cancer types with high PD-L1 expression, which suppressed the pre-existing immunity towards the tumor antigen (52). Therefore, the light chain and heavy chain of MPDL3280A was selected to produce a CAR together with an intracellular domain. To use PD-L1 as a novel target for the treatment of solid tumors with CAR-T cells, it was determined that $\mathrm{T}$ cells expressing $\mathrm{scFv}-28 \mathrm{z}$ did not attack nearby $\mathrm{T}$ cells, despite the fact that $\mathrm{T}$ cells expressed low PD-L1 (63), and the number of T cells was effectively amplified. This indicated that it may be safe to select PD-L1 as a target. The data indicated that CAR-T cells were able to release IFN- $\gamma$ at a high level when co-cultured with NCI-H358 cells, but not when co-cultured with $<100 \mathrm{pg} / \mathrm{ml}$ A549 cells, which demonstrated a PD-L1-specific interaction with scFv. Furthermore, low concentrations of IL- 2 and TNF- $\alpha$ were observed, reflecting that exposure to an antigen for a long 

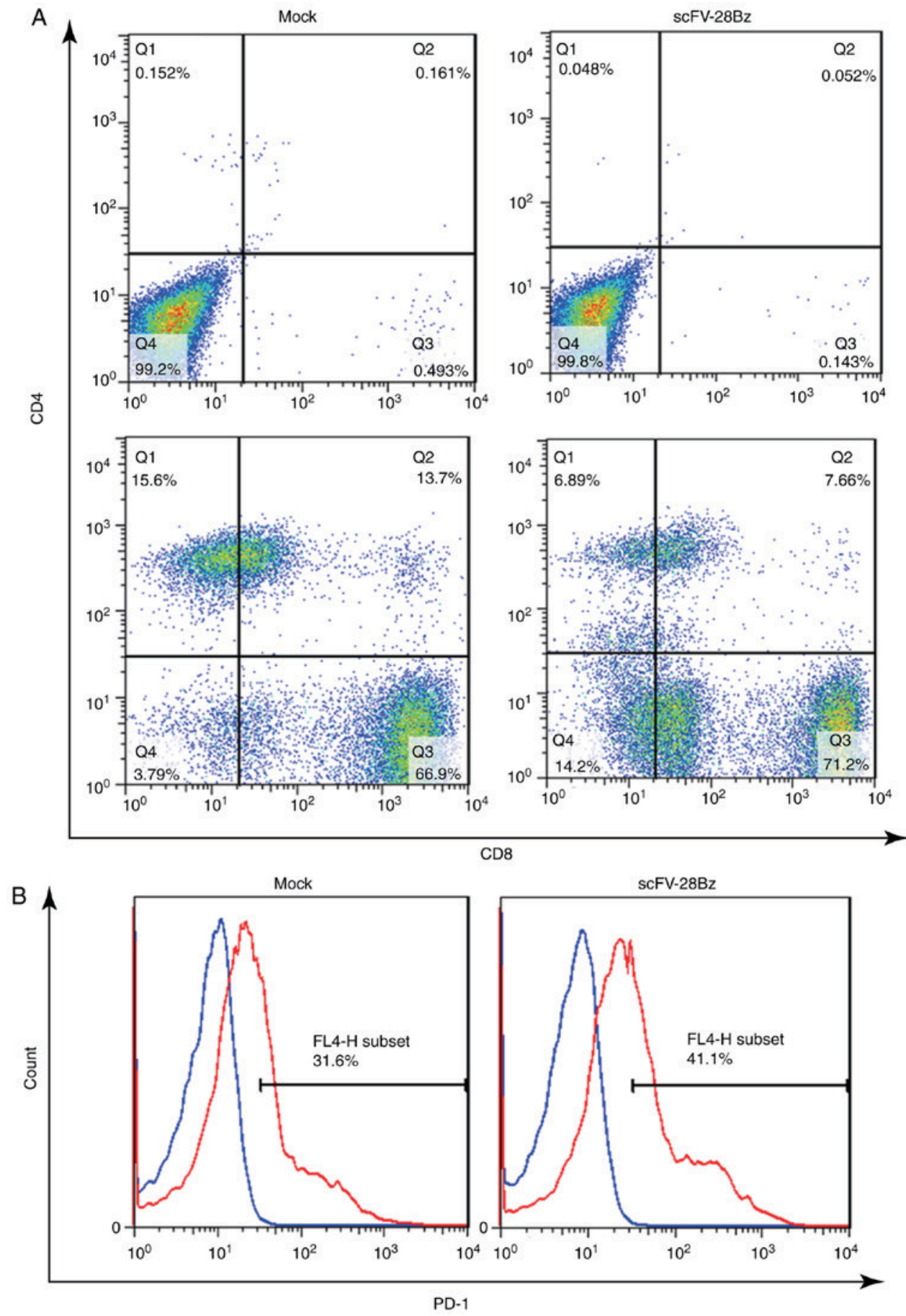

Figure 3. Analysis of PBMC phenotype. (A) Subsets of PBMCs as determined by flow cytometry. Transduced cells were collected and labeled with peridinin chlorophyll protein complex-CD4 and phycoerythrin-CD8 antibodies, with normal IgG serving as an isotype control. (B) PD-1 expression in PBMCs. Transduced cells were collected and labeled with an allophycocyanin-PD-1 antibody, with normal IgG as an isotype control. PBMCs, peripheral blood mononuclear cells; PD-1, programmed death-1; scFv, single-chain variable fragment; $\mathrm{CD}$, cluster of differentiation; IgG, immunoglobulin G.

time may lead to low cytokine production by T cells, which requires reversal by multiple simultaneous treatments (64). Similarly, the apoptosis assay revealed mild specific cytotoxicity against PD-L1-positive cells at an effector-to-target $\mathrm{T}$ ratio of 10:1. The results demonstrated that effectively blocking the PD-1 pathway may reactivate $\mathrm{T}$ cell activity that has been decreased due to PD-L1 expression in the solid tumor microenvironment. From another perspective, the moderate killing effect may be an ideal result of target blocking. Furthermore, the high level of PD-1 expression in
$\mathrm{T}$ cells, as depicted in Fig. 3, demonstrated that complete blocking of the signaling pathway by only one treatment may not be easy to implement, and that a variety of blocking methods, including combination with PD-1 blocking, may lead to improved results.

Studies on tumor therapy have indicated that the presence or absence of invasive $\mathrm{T}$ cells is critical in determining the response of patients to treatment. The inhibitory effect of the tumor microenvironment on immunity may manifest as the absence of infiltrating cells $(65,66)$. If tumor-specific 

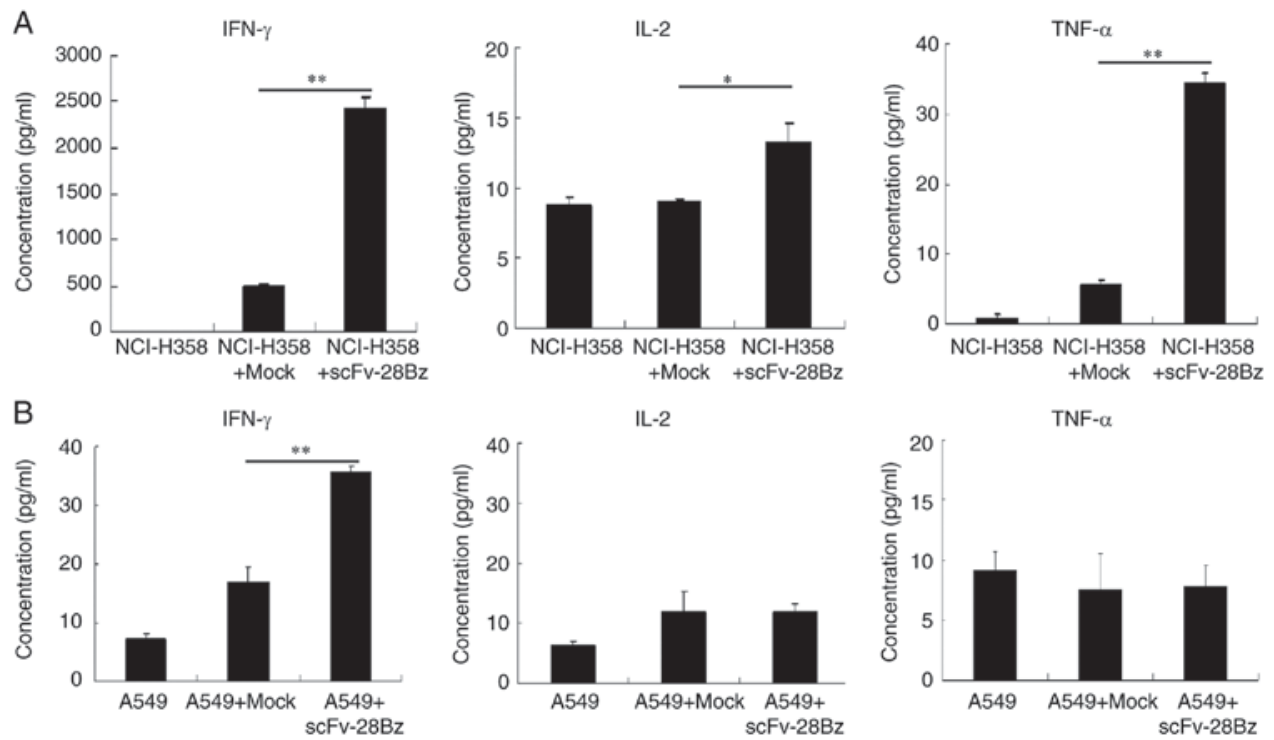

Figure 4. Cytokine production by T cells co-cultured with NCI-H358 or A549 cells. Modified T cells were co-cultured with (A) NCI-H358 or (B) A549 cells, and the cytokine levels in the supernatant were detected by ELISA in pg/ml. All assays were repeated three times and the results are presented as the mean \pm standard deviation of three independent experiments. " $\mathrm{P}<0.05 ;{ }^{* *} \mathrm{P}<0.01$. IL-2, interleukin-2; IFN, interferon; TNF, tumor necrosis factor; scFv, single-chain variable fragment.
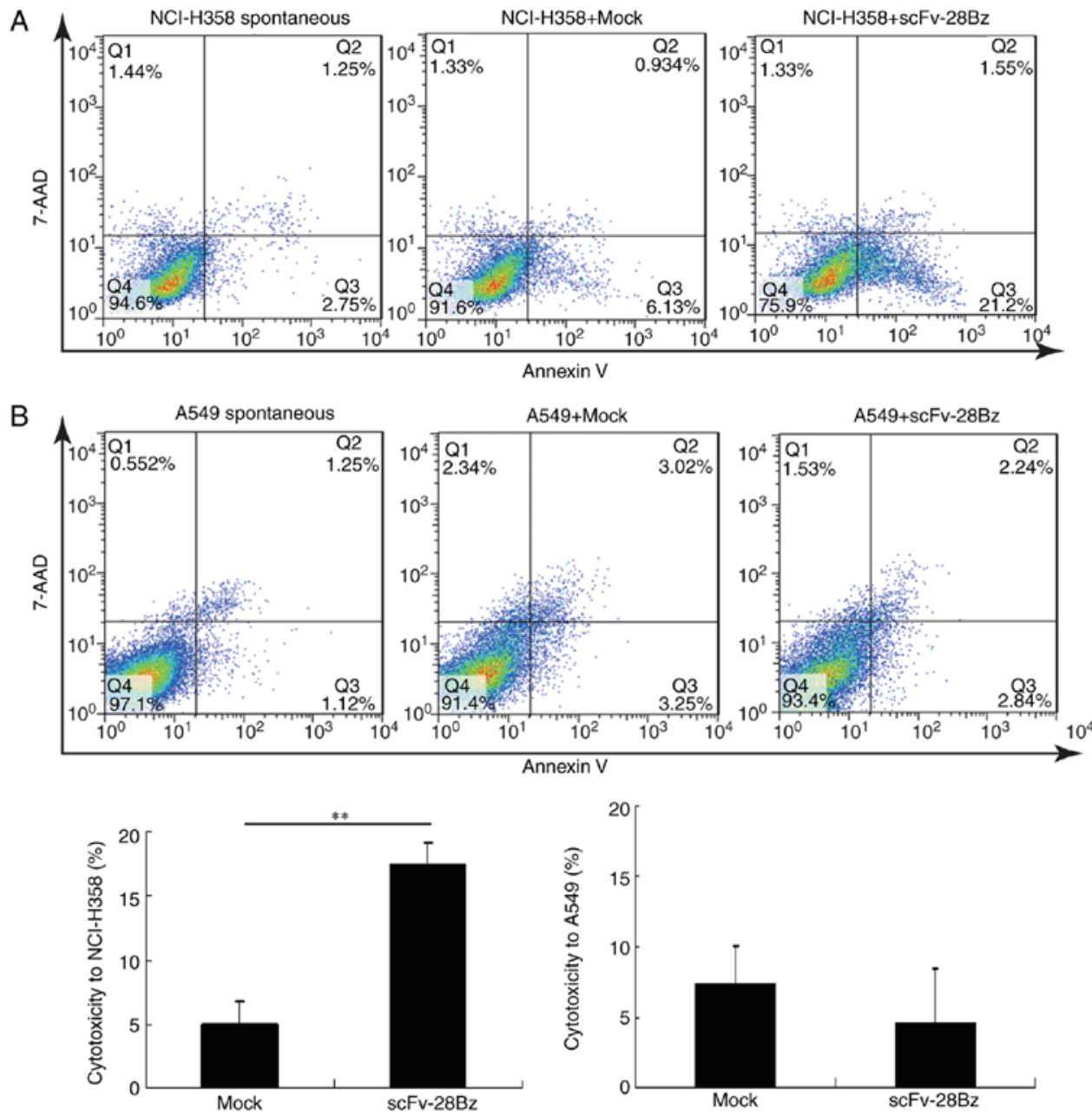

Figure 5. Chimeric antigen receptor-T cells demonstrated (A) specific cytotoxicity against PD-L1 ${ }^{+}$NCI-H358 cells, but had (B) no significant effect on A549

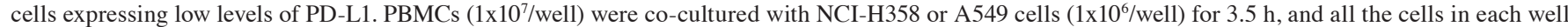
were then collected for use in Annexin V/7-AAD apoptosis assays. The specific cytotoxicity of PBMCs was equal to the total death of co-cultured target cells following subtraction of the total spontaneous death of non-co-cultured target cells [specific cytotoxicity $=\operatorname{target}_{\text {cell }}$ co-cultured $(\mathrm{Q} 1+\mathrm{Q} 2+\mathrm{Q} 3)$-target cell ${ }_{\text {non-co-cultured }}$ $(\mathrm{Q} 1+\mathrm{Q} 2+\mathrm{Q} 3)]$. The results are presented as the mean \pm standard deviation of three independent experiments. ${ }^{* *} \mathrm{P}<0.01 .7-\mathrm{AAD}, 7-\mathrm{aminoactinomycin}$; scFv, single-chain variable fragment; PD-L1, programmed death-ligand 1; PBMCs, peripheral blood mononuclear cells. 


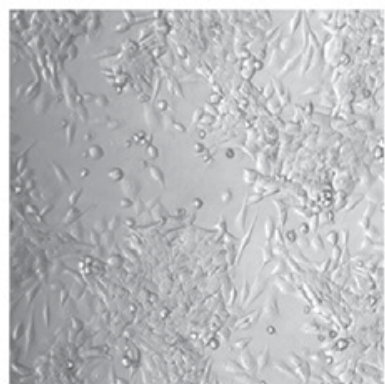

$\mathrm{NCl}-\mathrm{H} 358$

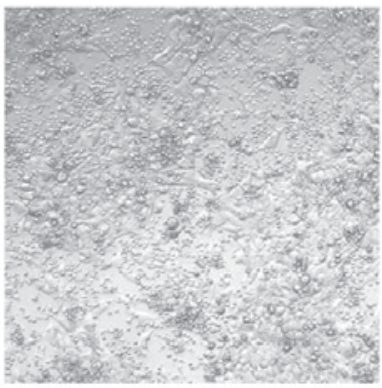

$\mathrm{NCl}-\mathrm{H} 358+$ mock

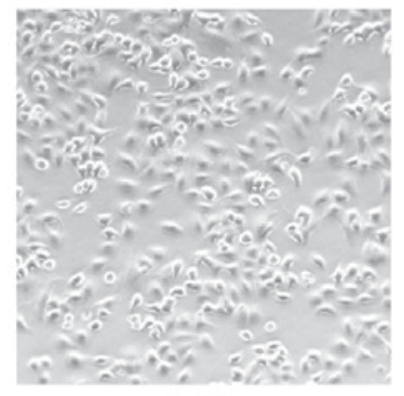

A549

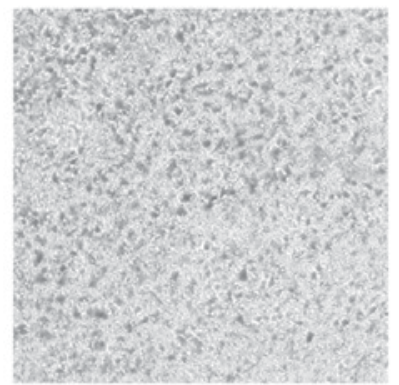

A549+mock

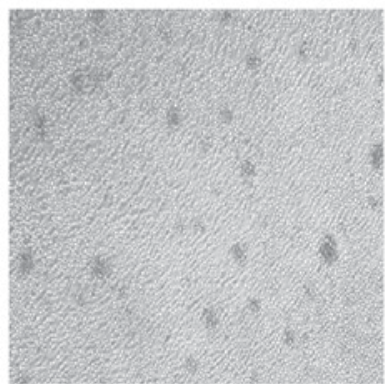

Mock

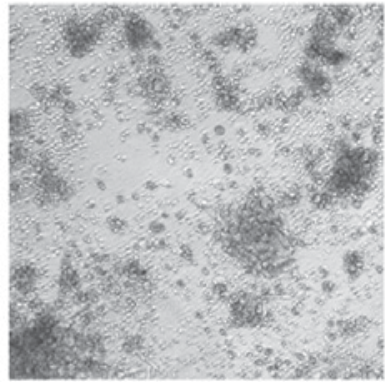

$\mathrm{NCl}-\mathrm{H} 358+\mathrm{scFv}-28 \mathrm{Bz}$

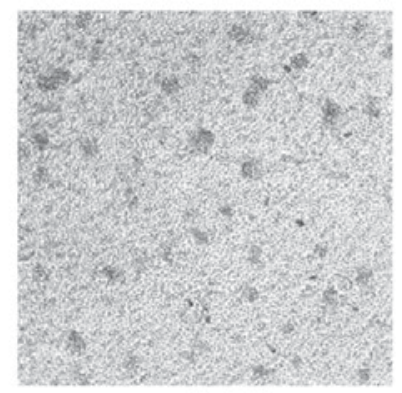

scFv-28Bz

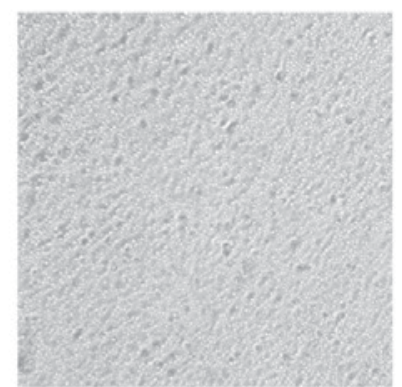

A549+scFv-28Bz

Figure 6. Morphology of co-cultured cells demonstrated specific cytotoxicity of chimeric antigen receptor-T cells against PD-L1 ${ }^{+}$NCI-H358 cells, but no significant effect on A549 cells expressing low levels of PD-L1. NCI-H358 cells, A549 cells, mock cells and scFv-28Bz cells were cultured alone to maintain the integrity of morphology and to ensure good condition. Mock cells co-cultured with NCI-H358 or A549 cells had no effect on target cells. Co-culture of A549 cells with scFv-28Bz cells had no effect on the morphology of A549 cells. The morphological integrity and adherent ability of NCI-H358 cells decreased when co-cultured with scFv-28Bz cells. scFv, single-chain variable fragment; PD-L1, programmed death-ligand 1.

$\mathrm{T}$ cells are unable to effectively reach the tumor cells and to accumulate in their vicinity, it is not possible to remove the tumor cells (18). By contrast, PD-L1-targeted T cells may avoid being weakened, and accumulate in the vicinity of tumor cells and infiltrate into the tumor to exert cytotoxic effect. As a therapeutic method, PD-L1 CAR-T presented its specificity against tumor cells with a high expression of PD-L1. PD-L1 CAR may be considered to be a shield and a probe that is directed toward tumor cells with high expression of PD-L1. This is of clinical significance for adoptive cell immunotherapy. During the T-cell immunotherapy, effective defense against PD-L1 in the tumor microenvironment is a prerequisite for maintaining a continuous antitumor effect $(28,62,67-69)$.

In summary, PD-L1-targeted CAR lentiviral vectors and efficiently transduced $\mathrm{T}$ cells were constructed. The CAR-T cells exerted a mild cytotoxic effect against a PD-L1-positive lung cancer cell line in vitro; however, this approach requires further optimization in order to obtain improved results.

The results indicated the possibility of treating tumors by targeting immune checkpoints in the tumor microenvironment, however it remains unknown whether CAR-T cells attack normal tissues expressing PD-L1. As the results of the present study demonstrate, it is confirmed that CAR-T does not attack nearby T-cells with low PD-L1 expression. In addition, PD-L1 CAR may be further developed to a dual target CAR to achieve improved safety and specificity.

\section{Acknowledgements}

The authors would like to thank Mr Hongbao Yao (Beijing Bio DC Labs, Beijing, China) for his technical assistance with the flow cytometry operation and Dr Xiaobin Chen (Beijing Bio DC Labs) for reviewing the manuscript.

\section{Funding}

The present study was supported by the National High Technology Research and Development Program of China (grant no. 2014AA022206).

\section{Availability of data and materials}

The datasets used and/or analyzed during the current study are available from the corresponding author on reasonable request.

\section{Authors' contributions}

JX and ZZ designed the experiments, analyzed the data and wrote the manuscript. SJ and XL contributed to the initial idea and approved the final version to be published.

\section{Ethics statement and consent to participate}

Not applicable.

\section{Consent for publication}

Not applicable.

\section{Competing interests}

The authors declare that they have no competing interests. 


\section{References}

1. Chen W, Zheng R, Baade PD, Zhang S, Zeng H, Bray F, Jemal A Yu XQ and He J: Cancer statistics in China, 2015. CA Cancer J Clin 66: 115-132, 2016.

2. Molina JR, Yang P, Cassivi SD, Schild SE and Adjei AA: Non-small cell lung cancer: Epidemiology, risk factors, treatment, and survivorship. Mayo Clin Proc 83: 584-594, 2008.

3. Herbst RS, Morgensztern D and Boshoff C: The biology and management of non-small cell lung cancer. Nature 553: 446-454, 2018.

4. Tanoue LT and Detterbeck FC: New TNM classification for non-small-cell lung cancer. Expert Rev Anticancer Ther 9: 413-423, 2009

5. Lemjabbar-Alaoui H, Hassan OU, Yang YW and Buchanan P: Lung cancer: Biology and treatment options. Biochim Biophys Acta 1856: 189-210, 2015.

6. Eshhar Z, Waks T, Gross G and Schindler DG: Specific activation and targeting of cytotoxic lymphocytes through chimeric single chains consisting of antibody-binding domains and the gamma or zeta subunits of the immunoglobulin and T-cell receptors. Proc Natl Acad Sci USA 90: 720-724, 1993.

7. Kochenderfer JN and Rosenberg SA: Treating B-cell cancer with T cells expressing anti-CD19 chimeric antigen receptors. Nat Rev Clin Oncol 10: 267-276, 2013.

8. Johnson LA and June CH: Driving gene-engineered $\mathrm{T}$ cell immunotherapy of cancer. Cell Res 27: 38-58, 2017.

9. Wang Z, Wu Z, Liu Y and Han W: New development in CAR-T cell therapy. J Hematol Oncol 10: 53, 2017.

10. Cooper LJ, Topp MS, Serrano LM, Gonzalez S, Chang WC, Naranjo A, Wright C, Popplewell L, Raubitschek A, Forman SJ and Jensen MC: T-cell clones can be rendered specific for CD19: Toward the selective augmentation of the graft-versus-B-lineage leukemia effect. Blood 101: 1637-1644, 2003.

11. Stirrups R: CAR T-cells for relapsed B-cell ALL in children and young adults. Lancet Oncol 19: e144, 2018.

12. Gilbert JA: CAR T-cells for relapsed B-cell ALL in adults Lancet Oncol 19: e143, 2018.

13. Zuo BL, Yan B, Zheng GX, Xi WJ, Zhang X, Yang AG and Jia LT: Targeting and suppression of HER3-positive breast cancer by $\mathrm{T}$ lymphocytes expressing a heregulin chimeric antigen receptor. Cancer Immunol Immunother 67: 393-401, 2018.

14. Byrd TT, Fousek K, Pignata A, Szot C, Samaha H, Seaman S, Dobrolecki L, Salsman VS, Oo HZ, Bielamowicz K, et al: TEM8/ANTXR1-Specific CAR T cells as a targeted therapy for triple-negative breast cancer. Cancer Res 78: 489-500, 2018.

15. Banerjee K, Kumar S, Ross KA, Gautam S, Poelaert B Nasser MW, Aithal A, Bhatia R, Wannemuehler MJ, Narasimhan B, et al: Emerging trends in the immunotherapy of pancreatic cancer. Cancer Lett 417: 35-46, 2018.

16. Park YP, Jin L, Bennett KB, Wang D, Fredenburg KM, Tseng JE, Chang LJ, Huang J and Chan EKL: CD70 as a target for chimeric antigen receptor $\mathrm{T}$ cells in head and neck squamous cell carcinoma. Oral Oncol 78: 145-150, 2018.

17. Till BG, Jensen MC, Wang J, Qian X, Gopal AK, Maloney DG, Lindgren CG, Lin Y, Pagel JM, Budde LE, et al: CD20-specific adoptive immunotherapy for lymphoma using a chimeric antigen receptor with both CD28 and 4-1BB domains: Pilot clinical trial results. Blood 119: 3940-3950, 2012

18. Fesnak AD, June CH and Levine BL: Engineered T cells: The promise and challenges of cancer immunotherapy. Nat Rev Cancer 16: 566-581, 2016.

19. Kalos M, Levine BL, Porter DL, Katz S, Grupp SA, Bagg A and June $\mathrm{CH}$ : $\mathrm{T}$ cells with chimeric antigen receptors have potent antitumor effects and can establish memory in patients with advanced leukemia. Sci Transl Med 3: 95ra73, 2011.

20. Lee DW, Kochenderfer JN, Stetler-Stevenson M, Cui YK, Delbrook C, Feldman SA, Fry TJ, Orentas R, Sabatino M, Shah NN, et al: $\mathrm{T}$ cells expressing CD19 chimeric antigen receptors for acute lymphoblastic leukaemia in children and young adults: A phase 1 dose-escalation trial. Lancet 385: 517-528, 2015.

21. Brentjens RJ, Davila ML, Riviere I, Park J, Wang X, Cowell LG, Bartido S, Stefanski J, Taylor C, Olszewska M, et al: CD19-targeted $\mathrm{T}$ cells rapidly induce molecular remissions in adults with chemotherapy-refractory acute lymphoblastic leukemia. Sci Transl Med 5: 177ra38, 2013.

22. Correction: Mesothelin-specific chimeric antigen receptor mRNA-engineered $\mathrm{T}$ cells induce antitumor activity in solid malignancies. Cancer Immunol Res 3: 217, 2015.
23. Brentjens RJ, Santos E, Nikhamin Y, Yeh R, Matsushita M, La Perle K, Quintás-Cardama A, Larson SM and Sadelain M: Genetically targeted $\mathrm{T}$ cells eradicate systemic acute lymphoblastic leukemia xenografts. Clin Cancer Res 13: 5426-5435, 2007.

24. Ishida Y, Agata Y, Shibahara K and Honjo T: Induced expression of PD-1, a novel member of the immunoglobulin gene superfamily, upon programmed cell death. EMBO J 11: 3887-3895, 1992.

25. Nishimura $H$, Nose $M$, Hiai $H$, Minato $N$ and Honjo $T$ : Development of lupus-like autoimmune diseases by disruption of the PD-1 gene encoding an ITIM motif-carrying immunoreceptor. Immunity 11: 141-151, 1999.

26. Keir ME, Butte MJ, Freeman GJ and Sharpe AH: PD-1 and its ligands in tolerance and immunity. Annu Rev Immunol 26: 677-704, 2008

27. Iwai $\mathrm{Y}$, Ishida M, Tanaka $\mathrm{Y}$, Okazaki T, Honjo T and Minato N: Involvement of PD-L1 on tumor cells in the escape from host immune system and tumor immunotherapy by PD-L1 blockade. Proc Natl Acad Sci USA 99: 12293-12297, 2002.

28. Taube JM, Klein A, Brahmer JR, Xu H, Pan X, Kim JH, Chen L, Pardoll DM, Topalian SL and Anders RA: Association of PD-1, PD-1 ligands, and other features of the tumor immune microenvironment with response to anti-PD-1 therapy. Clin Cancer Res 20: 5064-5074, 2014.

29. Sharpe AH, Wherry EJ, Ahmed R and Freeman GJ: The function of programmed cell death 1 and its ligands in regulating autoimmunity and infection. Nat Immunol 8: 239-245, 2007

30. Dong H, Zhu G, Tamada K and Chen L: B7-H1, a third member of the B7 family, co-stimulates T-cell proliferation and interleukin-10 secretion. Nat Med 5: 1365-1369, 1999.

31. Dong H, Strome SE, Salomao DR, Tamura H, Hirano F, Flies DB, Roche PC, Lu J, Zhu G, Tamada K, et al: Tumor-associated B7-H1 promotes T-cell apoptosis: A potential mechanism of immune evasion. Nat Med 8: 793-800, 2002.

32. Freeman GJ, Long AJ, Iwai Y, Bourque K, Chernova T, Nishimura H, Fitz LJ, Malenkovich N, Okazaki T, Byrne MC, et al: Engagement of the PD-1 immunoinhibitory receptor by a novel B7 family member leads to negative regulation of lymphocyte activation. J Exp Med 192: 1027-1034, 2000.

33. Inoue Y, Yoshimura K, Mori K, Kurabe N, Kahyo T, Mori H, Kawase A, Tanahashi M, Ogawa H, Inui N, et al: Clinical significance of PD-L1 and PD-L2 copy number gains in non-small-cell lung cancer. Oncotarget 7: 32113-32128, 2016.

34. Konishi J, Yamazaki K, Azuma M, Kinoshita I, Dosaka-Akita H and Nishimura M: B7-H1 expression on non-small cell lung cancer cells and its relationship with tumor-infiltrating lymphocytes and their PD-1 expression. Clin Cancer Res 10: 5094-5100, 2004.

35. Akbay EA, Koyama S, Carretero J, Altabef A, Tchaicha JH, Christensen CL, Mikse OR, Cherniack AD, Beauchamp EM, Pugh TJ, et al: Activation of the PD-1 pathway contributes to immune escape in EGFR-driven lung tumors. Cancer Discov 3: $1355-1363,2013$

36. Topalian SL, Hodi FS, Brahmer JR, Gettinger SN, Smith DS, McDermott DF, Powderly JD, Carvajal RD, Sosman JA, Atkins MB, et al: Safety, activity, and immune correlates of anti-PD-1 antibody in cancer. N Engl J Med 366: 2443-2454, 2012.

37. Brahmer JR, Tykodi SS, Chow LQ, Hwu WJ, Topalian SL, Hwu P, Drake CG, Camacho LH, Kauh J, Odunsi K, et al: Safety and activity of anti-PD-L1 antibody in patients with advanced cancer. N Engl J Med 366: 2455-2465, 2012.

38. Brahmer J, Reckamp KL, Baas P, Crinò L, Eberhardt We, Poddubskaya E, Antonia S, Pluzanski A, Vokes EE, Holgado E, et al: Nivolumab versus docetaxel in advanced squamous-cell non-small-cell lung cancer. N Engl J Med 373: $123-135,2015$.

39. Garon EB, Rizvi NA, Hui R, Leighl N, Balmanoukian AS, Eder JP, Patnaik A, Aggarwal C, Gubens M, Horn L, et al: Pembrolizumab for the treatment of non-small-cell lung cancer. N Engl J Med 372: 2018-2028, 2015.

40. Fehrenbacher L, Spira A, Ballinger M, Kowanetz M, Vansteenkiste J, Mazieres J, Park K, Smith D, Artal-Cortes A, Lewanski C, et al: Atezolizumab versus docetaxel for patients with previously treated non-small-cell lung cancer (POPLAR): A multicentre, open-label, phase 2 randomised controlled trial. Lancet 387: 1837-1846, 2016. 
41. Suarez ER, Chang de K, Sun J, Sui J, Freeman GJ, Signoretti S, Zhu Q and Marasco WA: Chimeric antigen receptor T cells secreting anti-PD-L1 antibodies more effectively regress renal cell carcinoma in a humanized mouse model. Oncotarget 7 : 34341-34355, 2016.

42. Cherkassky L, Morello A, Villena-Vargas J, Feng Y, Dimitrov DS, Jones DR, Sadelain M and Adusumilli PS: Human CAR T cells with cell-intrinsic PD-1 checkpoint blockade resist tumor-mediated inhibition. J Clin Invest 126: 3130-3144, 2016

43. Kobold S, Grassmann S, Chaloupka M, Lampert C, Wenk S, Kraus F, Rapp M, Düwell P, Zeng Y, Schmollinger JC, et al: Impact of a new fusion receptor on PD-1-mediated immunosuppression in adoptive T cell therapy. J Natl Cancer Inst 107, 2015.

44. Liu X, Ranganathan R, Jiang S, Fang C, Sun J, Kim S, Newick K, Lo A, June CH, Zhao Y and Moon EK: A chimeric switch-receptor targeting PD1 augments the efficacy of second-generation CAR T cells in advanced solid tumors. Cancer Res 76: 1578-1590, 2016.

45. Davila ML, Riviere I, Wang X, Bartido S, Park J, Curran K, Chung SS, Stefanski J, Borquez-Ojeda O, Olszewska M, et al Efficacy and toxicity management of $19-28 z$ CAR T cell therapy in B cell acute lymphoblastic leukemia. Sci Transl Med 6: 224ra25, 2014

46. Savoldo B, Ramos CA, Liu E, Mims MP, Keating MJ, Carrum G, Kamble RT, Bollard CM, Gee AP, Mei Z, et al: CD28 costimulation improves expansion and persistence of chimeric antigen receptor-modified T cells in lymphoma patients. J Clin Invest 121: 1822-1826, 2011

47. Long AH, Haso WM, Shern JF, Wanhainen KM, Murgai M, Ingaramo M, Smith JP, Walker AJ, Kohler ME, Venkateshwara VR, et al: 4-1BB costimulation ameliorates $\mathrm{T}$ cell exhaustion induced by tonic signaling of chimeric antigen receptors. Nat Med 21: 581-590, 2015.

48. Zheng Z, Chinnasamy N and Morgan RA: Protein L: A novel reagent for the detection of chimeric antigen receptor (CAR) expression by flow cytometry. J Transl Med 10: 29, 2012.

49. Sommermeyer D, Hudecek M, Kosasih PL, Gogishvili T, Maloney DG, Turtle CJ and Riddell SR: Chimeric antigen receptor-modified $\mathrm{T}$ cells derived from defined CD8+ and CD4+ subsets confer superior antitumor reactivity in vivo. Leukemia 30: 492-500, 2016.

50. Liu X, Zhang Y, Cheng C, Cheng AW, Zhang X, Li N, Xia C, Wei X, Liu X and Wang H: CRISPR-Cas9-mediated multiplex gene editing in CAR-T cells. Cell Res 27: 154-157, 2017.

51. Fischer K, Andreesen R and Mackensen A: An improved flow cytometric assay for the determination of cytotoxic T lymphocyte activity. J Immunol Methods 259: 159-169, 2002.

52. Herbst RS, Soria JC, Kowanetz M, Fine GD, Hamid O, Gordon MS, Sosman JA, McDermott DF, Powderly JD, Gettinger SN, et al: Predictive correlates of response to the anti-PD-L1 antibody MPDL3280A in cancer patients. Nature 515: 563-567, 2014.

53. Siegel RL, Miller KD and Jemal A: Cancer statistics, 2016. CA Cancer J Clin 66: 7-30, 2016.

54. Siegel RL, Miller KD and Jemal A: Cancer Statistics, 2017. CA Cancer J Clin 67: 7-30, 2017.
55. Siegel RL, Miller KD and Jemal A: Cancer statistics, 2018. CA Cancer J Clin 68: 7-30, 2018.

56. Travis WD, Brambilla E and Riely GJ: New pathologic classification of lung cancer: Relevance for clinical practice and clinical trials. J Clin Oncol 31: 992-1001, 2013.

57. Porter DL, Hwang WT, Frey NV, Lacey SF, Shaw PA, Loren AW, Bagg A, Marcucci KT, Shen A, Gonzalez V, et al: Chimeric antigen receptor $\mathrm{T}$ cells persist and induce sustained remissions in relapsed refractory chronic lymphocytic leukemia. Sci Transl Med 7: 303ra139, 2015.

58. Patel SP and Kurzrock R: PD-L1 expression as a predictive biomarker in cancer immunotherapy. Mol Cancer Ther 14: 847-856, 2015.

59. McDermott DF and Atkins MB: PD-1 as a potential target in cancer therapy. Cancer Med 2: 662-673, 2013.

60. Baruch K, Deczkowska A, Rosenzweig N, Tsitsou-Kampeli A, Sharif AM, Matcovitch-Natan O, Kertser A, David E, Amit I and Schwartz M: PD-1 immune checkpoint blockade reduces pathology and improves memory in mouse models of Alzheimer's disease. Nat Med 22: 135-137, 2016.

61. John LB, Devaud C, Duong CP, Yong CS, Beavis PA, Haynes NM, Chow MT, Smyth MJ, Kershaw MH and Darcy PK: Anti-PD-1 antibody therapy potently enhances the eradication of established tumors by gene-modified T cells. Clin Cancer Res 19 5636-5646, 2013.

62. Powles T, Eder JP, Fine GD, Braiteh FS, Loriot Y, Cruz C, Bellmunt J, Burris HA, Petrylak DP, Teng SL, et al: MPDL3280A (anti-PD-L1) treatment leads to clinical activity in metastatic bladder cancer. Nature 515: 558-562, 2014.

63. Keir ME, Francisco LM and Sharpe AH: PD-1 and its ligands in T-cell immunity. Curr Opin Immunol 19: 309-314, 2007.

64. Gargett T, Yu W, Dotti G, Yvon ES, Christo SN, Hayball JD, Lewis ID, Brenner MK and Brown MP: GD2-specific CAR $\mathrm{T}$ cells undergo potent activation and deletion following antigen encounter but can be protected from activation-induced cell death by PD-1 blockade. Mol Ther 24: 1135-1149, 2016.

65. Joyce JA and Fearon DT: T cell exclusion, immune privilege, and the tumor microenvironment. Science 348: 74-80, 2015

66. Feig C, Jones JO, Kraman M, Wells RJ, Deonarine A, Chan DS, Connell CM, Roberts EW, Zhao Q, Caballero OL, et al: Targeting CXCL12 from FAP-expressing carcinoma-associated fibroblasts synergizes with anti-PD-L1 immunotherapy in pancreatic cancer. Proc Natl Acad Sci USA 110: 20212-20217, 2013.

67. Sharma P and Allison JP: The future of immune checkpoint therapy. Science 348: 56-61, 2015.

68. Zou W and Chen L: Inhibitory B7-family molecules in the tumour microenvironment. Nat Rev Immunol 8: 467-477, 2008.

69. Chen DS and Mellman I: Oncology meets immunology: The cancer-immunity cycle. Immunity 39: 1-10, 2013. International (CC BY-NC-ND 4.0) License. 